\title{
Potential of forest plants as foodstuffs in KPHP Unit VIII Muntai Palas, South Bangka Regency
}

\author{
Chairullah $^{\mathrm{a}}$, Ervizal AM Zuhud ${ }^{\mathrm{b}}$, Edy Nasriadi Sambas ${ }^{\mathrm{c}}$ \\ a Study Program of Natural Resources and Environmental Management, Graduate School, Bogor Agricultural \\ University, Baranangsiang Campus IPB University, Bogor, 16144, Indonesia [+62 8118885795] \\ ${ }^{\mathrm{b}}$ Chair of the Advisory Commission, Department of Forest Resources Conservation and Ecotourism, Faculty of \\ Forestry and Environment, IPB University, IPB Dramaga Campus, Bogor, 16680, Indonesia [0251 8621562, \\ 8621947/0251 8621947] \\ c Member of the Advisory Commission, Conservation and Environmental Management Expert
}

\section{Article Info:}

Received: 28 - 08 - 2021

Accepted: 26 - $10-2021$

Keywords:

AHP-SWOT, foodstuffs, KPH,

LUVI, vegetation analysis

\section{Corresponding Author:}

Chairullah

Study Program of Natural

Resources and Environmental

Management, Graduate School,

IPB University;

Tel +628111637228

Email:

chairullah_basel@apps.ipb.ac.id

\begin{abstract}
Plants as forest food sources have potential comparative advantages as alternative resources. The existence of KPHP Unit VIII Muntai Palas as a management unit can improve the quality of forest management in South Bangka Regency, Bangka Belitung Islands Province. This research aimed to take an inventory, analyze the utilization, and formulate a conservation village development strategy. This research is explorative with determining four village locations (Kepoh, Pasir Putih, Batu Betumpang, and Bencah) and selecting informants by purposive sampling. The study results found 33 families, 54 genera, 73 species with a total of 1858 individuals consisting of 1071 seedlings, 385 saplings, 173 poles, and 226 trees. The highest value of species diversity in the medium category was found in Kepoh village, while the highest value of importance (LUVI) differed in each observation village. Kepoh was owned by Sandoricum koetjape Village (LUVI 11.14), Pasir Putih village was mostly inhabitated by Mangifera odorata (kuweni) with a LUVI value of 9.68, Batu Betumpang Village was mostly covered by Nephelium lappaceum (rambutan) (LUVI 11.20) and Bencah village (LUVI 10.84) belongs to Garcinia nigrolineata (kandis). The StrengthOpportunity $(\mathrm{SO})$ strategy was applied in the development of sustainable forest conservation villages with the support of the diversity of forest food sources and regional policies as well as opportunities for the development of tourism forests, health forests, educational forests, natural laboratories and investment in natural resources and the environment to realize a sovereign forest conservation village independent food.
\end{abstract}

How to cite (CSE Style $8^{\text {th }}$ Edition):

Chairullah, Zuhud EAM, Sambas EN. 2021. Potential of forest plants as foodstuffs in KPHP Unit VIII Muntai Palas, South Bangka Regency. JPSL 11(4): 587-600. http://dx.doi.org/10.29244/jpsl.11.4.587-600.

\section{INTRODUCTION}

Utilization and preservation of forest food source plants cannot be separated from the activities of the community around the area, where people's lives are very dependent on the forest, then local wisdom appears which is contained in community ethnobotany in the use and preservation of forests. According to Zuhud (2011) Indonesia's tropical forests which consist of various types of ecosystems are a repository of biodiversity for more than 239 species of food plants and more than 2039 species of medicinal plants. 
In the Province of the Bangka Belitung Islands, as a tin island, quite a lot of land contains deposits or minerals such as tin, granite, kaolin, quartz and others in the forest area. Mining activities, plantations and illegal logging of trees have caused a lot of forest degradation. so that the potential of the forest as a forest food source plant habitat needs a potential study.

The establishment of KPHP Unit VIII Muntai Palas in South Bangka Regency based on the decision of the Minister of Forestry of the Republic of Indonesia number: SK.797/MENHUT-II/2009 concerning the determination of the area for the protected forest management unit (KPHL) and the production forest management unit (KPHP) of the Bangka Belitung Islands Province. They have duties and functions, among others, to organize forest management and open investment opportunities to support forest management objectives. Forest management is one of the government's efforts to save forest plant species that can be utilized, forest protection, and nature conservation for economic, social, and environmental interests. Local people have long used the types of forest food plants, but they have not been well documented, so they do not know how many species there are and what they are used for. The usefulness of plants as food sources is generally known by people who are old because along with the development of science and technology, many people have forgotten the benefits of forests as biological resources.

This research was conducted to obtain basic information (baseline) of forest food source plants and analyze the use of plants by the community and formulate a community-based development strategy for community-based forest food source plant conservation development strategies (Figure 1).

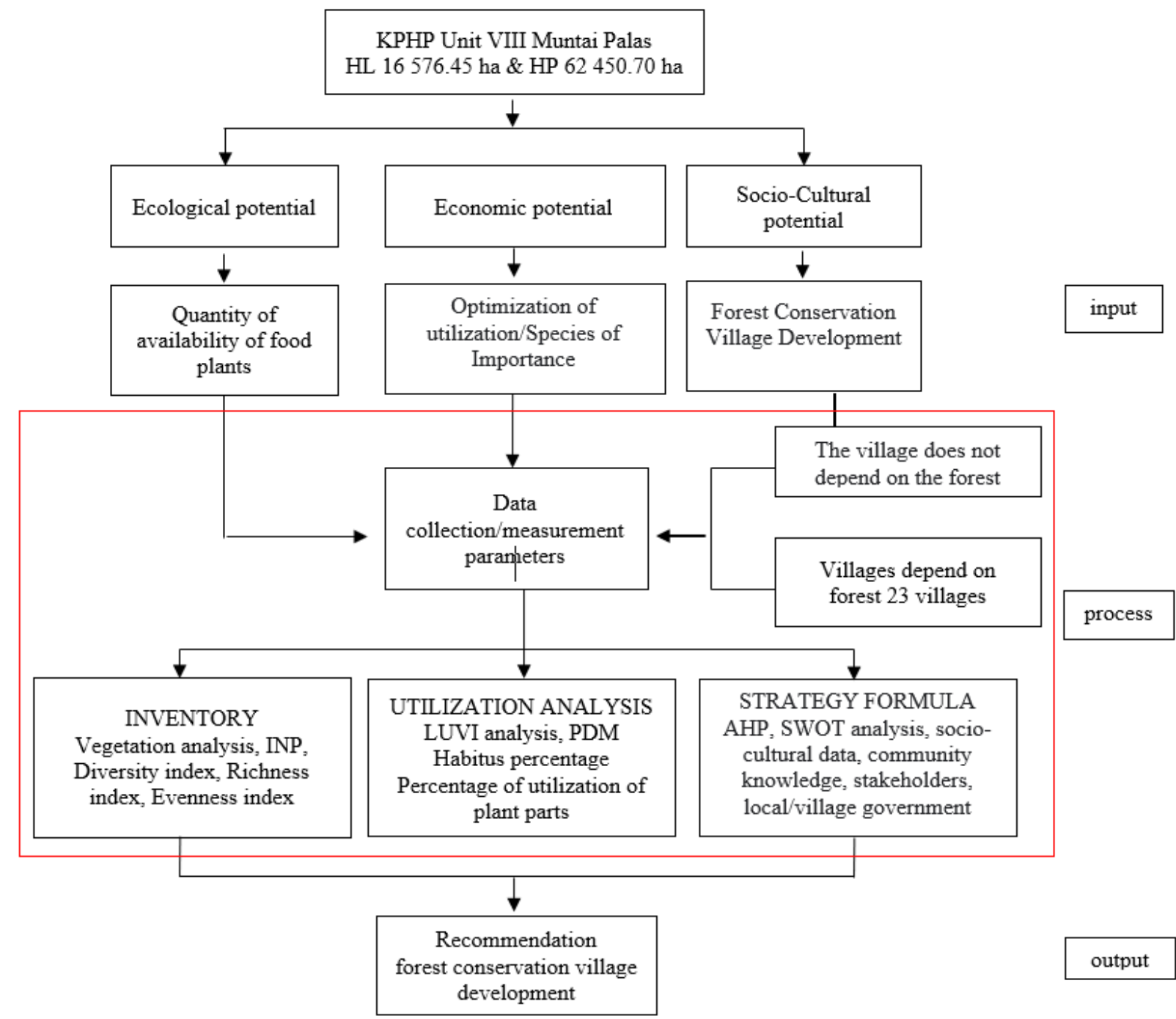

Figure 1 Research flow 


\section{METHOD}

\section{Location and Time}

The research was conducted at KPHP Unit VIII Muntai Palas, South Bangka Regency, Bangka Belitung Islands Province. Geographically it is located between 107² $14^{\prime} 31^{\prime \prime}-105^{\circ} 53^{\prime} 9^{\prime \prime}$ east longitude and $2^{\circ} 26^{\prime} 27^{\prime \prime}-$ $3^{\circ} 5^{\prime} 56$ " south latitude. The research locations are in four villages, namely Kepoh village, Pasir Putih village, Batu Betumpang village and Bencah village which are in the management area of KPHP Unit VIII Muntai Palas (Figure 2). This research was completed from May-December 2020.

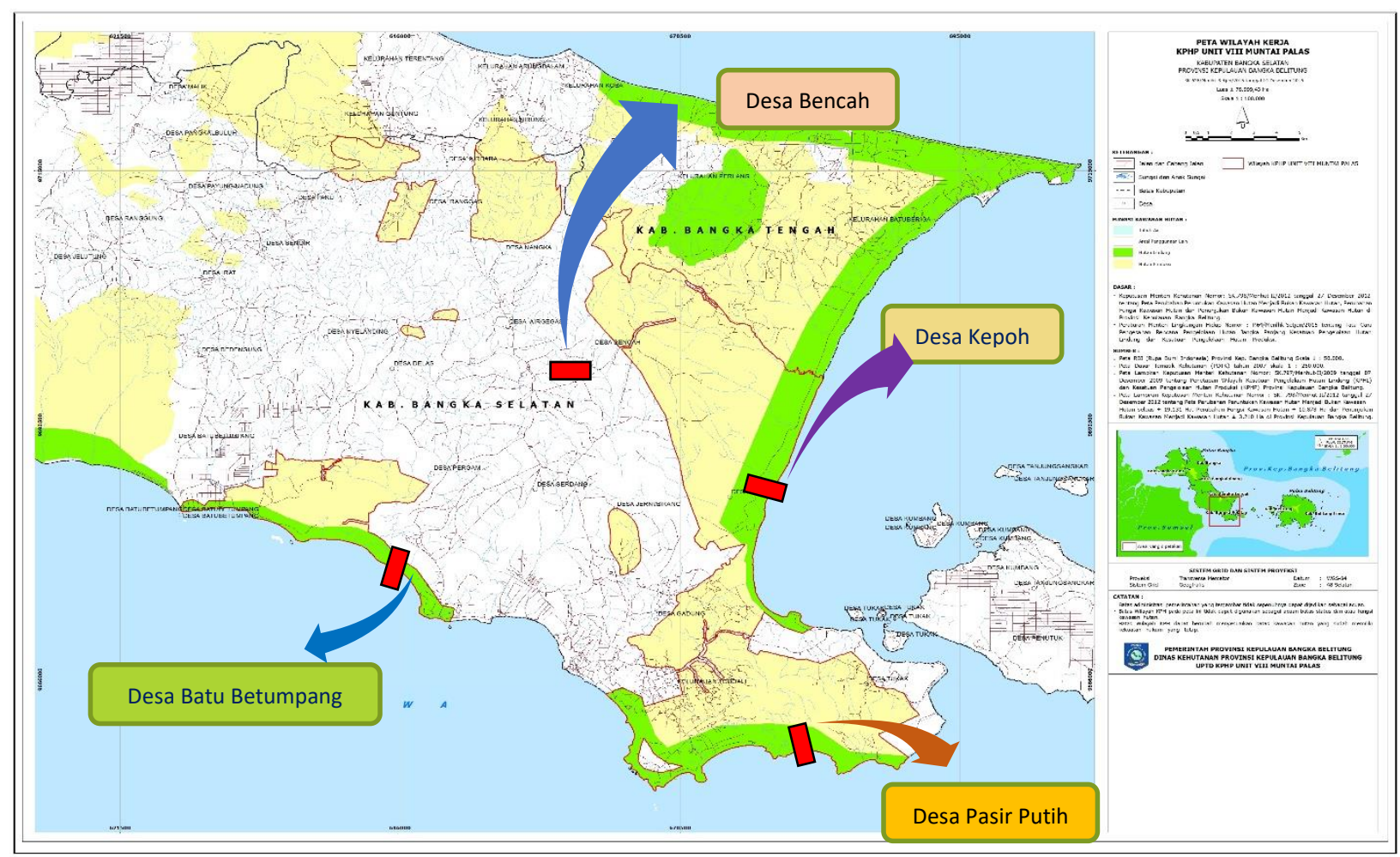

Figure 2 Research location (KLHK, 2018)

\section{Materials and Tools}

The materials used include 70\% alcohol, newsprint for making herbarium, while the tools used include a Nikon D5600 camera, GPS Garmin 64c, recorder, compass, measuring rope, stationery, tally sheet. Identification of plants in collaboration with the Research Center for Plant Conservation and Botanical Garden LIPI-Bogor.

\section{Data Collection Methods}

Data collection methods in this study were carried out through library research, interview, observation, vegetation analysis, identification of herbarium sample, and identification of plant species as forest food sources. The process of collecting qualitative data is done through a literature study and interviews. Interviews are usually conducted before conducting a field survey and serve as cross-check material for the presence of plants in the field (Togola et al. 2005).

Interviews in this study were conducted by means of group interviews as a measuring tool that reflects the community's perspective (Frey and Fontana, 2009) and purposive sampling method, namely to 40 key informants and eight primary informants in an open-ended way who are considered to understand the problems and research themes and have time to get involved. The observation data is quantitative using a combination 
method of striped and plotted lines (Kusmana 2017) with a total area of 4 hectar or 1 hectar (20x500) $\mathrm{m}^{2}$ per village. The size of each location was divided into 25 plots which contained observation plots with the size of tree growth rate $(20 \times 20) \mathrm{m}^{2}$, saplings $(5 \times 5) \mathrm{m}^{2}$, while seedlings $(2 \times 2) \mathrm{m}^{2}$ (Figure 3 ).

Data collected at the seedling level included the species name, the number of individuals of reach species, while for sapling, poles and trees the species name, number of individuals of each species, and stem diameter were recorded (Table 1).

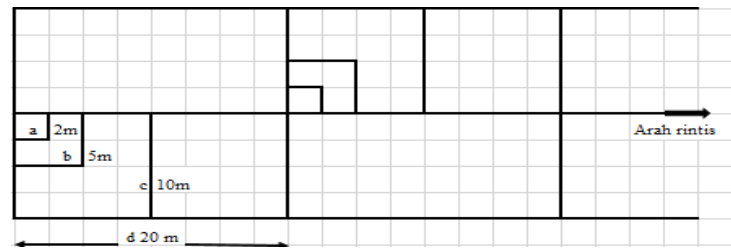

Figure 3 Design of the combination of the path method with the checkered line method (Kusmana, 2017)

Table 1 Types of data and information

\begin{tabular}{|c|c|c|c|c|}
\hline No & Aim & Data Type & Source & Methods and Analysis \\
\hline 1 & $\begin{array}{l}\text { Inventory the } \\
\text { potential of } \\
\text { forest food } \\
\text { plants as a } \\
\text { baseline for } \\
\text { management, } \\
\text { conservation, } \\
\text { and utilization. }\end{array}$ & $\begin{array}{l}\text { - Plant species } \\
\text { - Village data } \\
\text { - Local/regional name } \\
\text { - Scientific name (surname, } \\
\text { family) } \\
\text { - Rod diameter } \\
\text { - Stem height } \\
\text { - Density/relative density } \\
\text { - Relative } \\
\text { frequency/frequency } \\
\text { - Relative } \\
\text { dominance/dominance } \\
\text { - Species diversity } \\
\text { - Species richness } \\
\text { - Evenness of species }\end{array}$ & $\begin{array}{l}\text { - Community } \\
\text { unit of } \\
\text { analysis } \\
\text { - BPS (2021) } \\
\text { - KPHP Unit } \\
\text { VIII Muntai } \\
\text { Palas } \\
\text { - Herbarium } \\
\text { - Species } \\
\text { identification } \\
\text { manual }\end{array}$ & $\begin{array}{l}\text { - Questionnaire/Interview/FGD } \\
\text { - Literature review } \\
\text { - Observation } \\
\text { - Documentation } \\
\text { - Vegetation analysis } \\
\text { (Kusmana, 2017) } \\
\text { - Important Value Index (IVI) } \\
\text { - Species Diversity Index } \\
\text { (Shannon-Wienner) } \\
\text { - Species Richness Index } \\
\text { (Margalef) } \\
\text { - Evenness Index }\end{array}$ \\
\hline 2 & $\begin{array}{l}\text { Analyzing the } \\
\text { use of forest } \\
\text { food source } \\
\text { plants in KPHP } \\
\text { Unit VIII } \\
\text { Muntai Palas, } \\
\text { South Bangka } \\
\text { Regency }\end{array}$ & $\begin{array}{l}\text { - Species importance } \\
\text { - Parts of plants used } \\
\text { - Functional classification of } \\
\text { plants } \\
\text { - How to use the species } \\
\text { - Specific habitus data }\end{array}$ & $\begin{array}{l}\text { - Unit of } \\
\text { analysis } \\
\text { informants } \\
\text { - Observation }\end{array}$ & $\begin{array}{l}\text { - LUVI analysis (Sheil et al., } \\
\text { 2004) } \\
\text { - PDM (Pebble Distribution } \\
\text { Method) } \\
\text { (Gadgil et al., 2000) } \\
\text { - Analysis of plant use } \\
\text { - Deep interview }\end{array}$ \\
\hline 3 & $\begin{array}{l}\text { Formulate } \\
\text { community- } \\
\text { based forest } \\
\text { food source } \\
\text { plant } \\
\text { conservation } \\
\text { village } \\
\text { development } \\
\text { strategies }\end{array}$ & $\begin{array}{l}\text { - Factor weight data } \\
\text { - Factor rating data } \\
\text { - Factor scoring data }\end{array}$ & $\begin{array}{l}\text { - Informants } \\
\text { - Village head } \\
\text { - Bappeda }\end{array}$ & $\begin{array}{l}\text { - Questionnaire } \\
\text { - Interview } \\
\text { - Hierarchys Process Analysis } \\
\text { (AHP) (Saaty, 1991) } \\
\text { - SWOT analysis (Rangkuti } \\
\text { 1997) }\end{array}$ \\
\hline
\end{tabular}




\section{Data Analysis Method}

\section{Plant Inventory Data}

\section{Important value index (IVI)}

IVI describes the ecological position of a species against other species in a community. According to Soerianegara and Indrawan (1998), the formula used in calculating the Important Value Index (IVI) is:

Relative density (KR)

Relative frequency (FR)

Relative dominance (DR) Important Value Index (IVI)

IVI for seedling and undergrowth $(\%)=\mathrm{KR}+\mathrm{FR}$

\section{Species diversity index}

The value of species diversity is determined by using the Shannon-Wienner index formula:

$$
\mathrm{H}^{\prime}=-\Sigma \text { pi } \ln \mathrm{pi}
$$

Information:

$\mathrm{H}^{\prime}=$ Index of Diversity; $\mathrm{pi}=$ the proportion of the number of individuals of the its species $(\mathrm{ni} / \mathrm{N})$; ni= the number of individuals of the I-th species; $\mathrm{N}=$ the total number of individuals of all species.

\section{Species richness index}

Species diversity can be measured using the margalef formula (Clifford and Stephenson, 1975 in Magurran, 1988):

$$
\operatorname{DMg}=\frac{(\mathrm{S}-1)}{\operatorname{Ln} \mathrm{N}}
$$

Information:

$\mathrm{DMg}=$ margalef index; $\mathrm{S}=$ number of species observed; $\mathrm{Ln}=$ normal logarithm; $\mathrm{N}=$ total number of observed individuals.

\section{Species evenness index}

The evenness of species (evenness index) (Odum, 1993) with the formula:

Information:

$$
\mathrm{E}=\frac{\mathrm{H}^{\prime}}{\operatorname{Ln} \mathrm{S}}
$$

$\mathrm{E}=$ species evenness index; $\mathrm{H}^{\prime}=$ shannon index; $\mathrm{S}=$ number of observed species found; $\mathrm{Ln}=$ natural logarithm.

\section{Plant Utilization Analysis}

\section{Local user's value index (LUVI) value}

LUVI is the level of importance possessed by a species as a whole even though the interests are different (CIFOR, 2000). The specific method used is the scoring approach (pebble distribution method (PDM) and the unit sample area of variation (Gadgil et al., 2000).

$$
\begin{aligned}
\text { LUVI } & =\sum \mathrm{j} \text { species, total } \mathrm{j}, \mathrm{Gij} \\
\text { Gij } & =\sum \text { category } \mathrm{J} \text { Gij }=\mathrm{RWJ} \times \mathrm{RWij}
\end{aligned}
$$




\section{Description:}

Gij= the importance of a type of use (j) of a species (i); RWJ= the weight assigned to a broad class of uses, where certain uses $\mathrm{j}$ are located $\mathrm{RWij}=$ relative weight in category $\mathrm{j}$ in the utilization of species $\mathrm{i}$ that qualifies as a member-member $\mathrm{j}$.

\section{Plant utilization analysis}

$$
\begin{gathered}
\text { Percentage of certain habitus }=\frac{\sum \text { certain species of habitus used }}{\sum \text { total species }} \times 100 \% \\
\text { Percentage of parts utilized }=\frac{\sum \text { certain parts used }}{\sum \text { total part used }} \times 100 \%
\end{gathered}
$$

\section{Conservation Village Development Strategy}

\section{AHP and SWOT Analysis}

AHP is a multi criteria decision making technique in which quantitative and qualitative factors are combined so that priorities, positions and evaluations of alternatives can be carried out (Saaty, 1991). In this study, the calculation of the weight of each criterion used the AHP method with the help of R-Studio software and the computer program Excel 2016.

SWOT analysis is a strategic planning technique that is useful for evaluating the strengths and weaknesses, opportunities, and threats in a project (Figure 4). To get the rating value for each criteria for developing a forest conservation village, a strategy formulation using SWOT analysis is generated. SWOT analysis was first introduced by Albert S Humphrey in the 1960s when he led a research project at the Stanford Research Institute using data from Fortune 500 companies. This analysis can logically help in the decisionmaking process. The decision-making process is related to the vision and mission as well as the objectives of the research project. So that SWOT analysis can be used as an effective tool to analyze the factors that affect the company as a decision-making process to determine strategy.

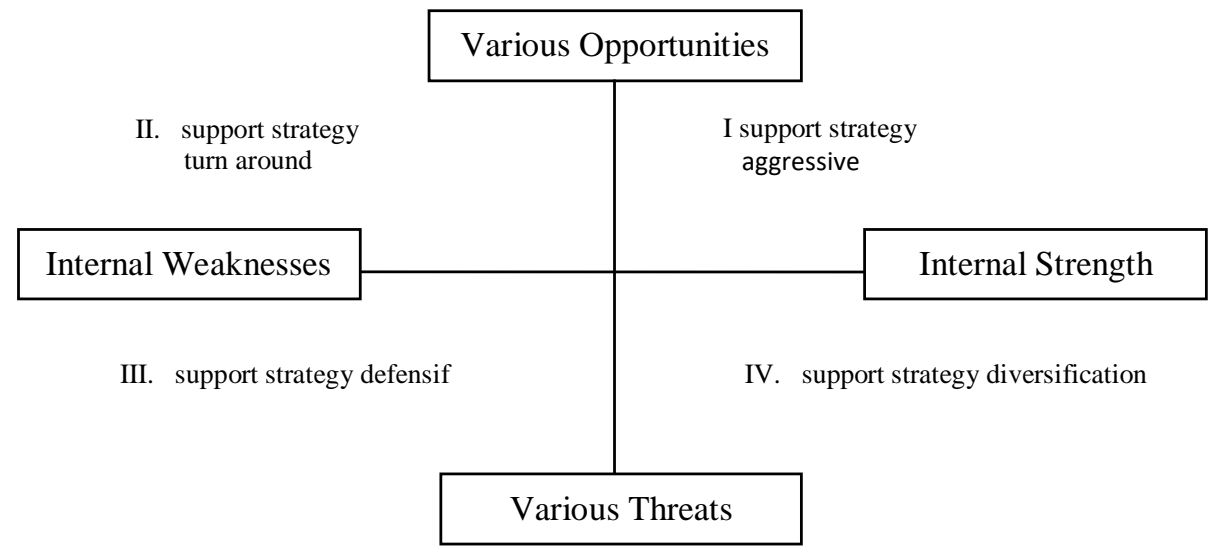

Figure 4 SWOT analysis (Solusu, 2000)

\section{RESULTS AND DISCUSSION}

\section{Inventory of Forest Food Source Plants}

After making observations to all observation points using the vegetation analysis data collection method, the results recorded were 73 species, 54 genera and 33 families with a total of 1858 individuals with details on the number at the seedling level as many as 1071 individuals, sapling level 385 individuals, pole level 172 
individuals and trees 226 individual. Thirty three (33) families with the most species, Myrtaceae (13 species) followed by Arecaceae (7 species), Sapindaceae, and Melastomataceae (5 species) as shown in Table 2.

Table 2 Number of species and individuals of forest food source plants observed at all growth levels in KPHP Area of Unit VIII Muntai Palas, South Bangka Regency

\begin{tabular}{|c|c|c|c|c|c|c|c|}
\hline \multirow{2}{*}{ No } & \multirow{2}{*}{ Scientific name } & \multirow{2}{*}{ Famili } & \multicolumn{4}{|c|}{ Quantity Per Growth Rate } & \multirow[b]{2}{*}{$\Sigma$} \\
\hline & & & Seedling & Sapling & Poles & Trees & \\
\hline 1 & Ampelocisus korthalsii Planch & Vitaceae & 1 & - & - & - & 1 \\
\hline 2 & Anisophyllea disticha (Jack) Baill & Anisophylleaceae & 9 & 5 & - & - & 14 \\
\hline 3 & $\begin{array}{l}\text { Archidendron pauciflorum (Benth.) } \\
\text { C.Nielsen }\end{array}$ & Fabaceae & 1 & - & - & - & 1 \\
\hline 4 & Artocarpus integer (Thunb.) Merr & Moraceae & - & - & - & 1 & 1 \\
\hline 5 & Artocarpus lacucha Buch-Ham & Moraceae & - & - & 1 & 1 & 2 \\
\hline 6 & Avicennia alba Blume & Acanthaceae & - & - & - & 1 & 1 \\
\hline 7 & Blumeodendron tokbrai (Blume) Kurz & Euphorbiaceae & - & 1 & - & - & 1 \\
\hline 8 & Bridelia tomentosa Blume & Phyllanthaceae & 1 & 2 & - & 5 & 8 \\
\hline 9 & Calamus melanochaetes (blume) & Arecaceae & 36 & - & - & - & 36 \\
\hline 10 & Calophyllum inophyllum $\mathrm{L}$ & Clusiaceae & - & 4 & - & - & 4 \\
\hline 11 & Caryota mitis Lour. & Arecaceae & 19 & 19 & 10 & 2 & 50 \\
\hline 12 & Centrosema pubescens Benth. & Fabaceae & 8 & - & - & - & 8 \\
\hline 13 & Coffea canephora Pierre ex A Froehner & Rubiaceae & 1 & 1 & - & - & 2 \\
\hline 14 & Cratoxylum glaucum Korth & Hipericaceae & - & - & 14 & 50 & 64 \\
\hline 15 & Curculigo latifolia Dryand ex WT Aiton & Amarylidaceae & 1 & - & - & - & 1 \\
\hline 16 & Elaeis guineensis Jacq & Arecaceae & - & - & - & 2 & 2 \\
\hline 17 & Elaeocarpus obtusus Blume & Elaeocarpaceae & - & 1 & - & 1 & 2 \\
\hline 18 & $\begin{array}{l}\text { Elaeocarpus submonoceras subsp lasionyx } \\
\text { (Stapf ex Ridl.) Weibel }\end{array}$ & Elaeocarpaceae & 19 & 33 & 16 & 2 & 70 \\
\hline 19 & Eurycoma longifolia Jack. & Simaroubaceae & 1 & - & - & - & 1 \\
\hline 20 & Ficus fistulosa Reinw.ex Blume & Moraceae & - & 2 & 2 & - & 4 \\
\hline 21 & Ficus racemosa $\mathrm{L}$. & Moraceae & - & - & 1 & 3 & 4 \\
\hline 22 & Flacourtia rukam Zoll. and Mor & Salicaceae & 95 & 9 & - & 6 & 110 \\
\hline 23 & Garcinia nigrolineata Planch ex T Anderson & Clusiaceae & 47 & 30 & 1 & 2 & 80 \\
\hline 24 & Garcinia xanthochymus Hook.f.ex & Cluciaceae & 1 & 1 & - & 7 & 9 \\
\hline 25 & Gynotroches axillaris Blume & Rhizophoraceae & 17 & 37 & 6 & - & 60 \\
\hline 26 & Hornstedtia tomentosa (Blume) Bakh.f. & Zingiberaceae & 1 & - & - & - & 1 \\
\hline 27 & Ilex laevigata (Pursh) A Gray & Aquifoliaceae & 40 & 3 & - & - & 43 \\
\hline 28 & Labisia pumila (Blume.) Fern.-Vill. & Primulaceae & 8 & - & - & - & 8 \\
\hline 29 & Lansium domesticum Corr & Meliaceae & - & - & 1 & - & 1 \\
\hline 30 & Leea indica (Burm f) Merr & Vitaceae & 4 & 7 & - & - & 11 \\
\hline 31 & Lepisanthes amoena (Hassk.) Leenh. & Sapindaceae & - & 1 & - & - & 1 \\
\hline 32 & Licuala spinosa Wurmb & Arecaceae & 2 & - & - & - & 2 \\
\hline 33 & Lijndenia laurina Zoll. and Moritzi & Melastomataceae & 16 & 4 & - & - & 20 \\
\hline 34 & Mangifera caesia Jack ex Wall & Anacardiaceae & - & - & - & 1 & 1 \\
\hline 35 & Mangifera odorata Griffith & Anacardiaceae & - & - & - & 7 & 7 \\
\hline 36 & Melastoma malabathricum $\mathrm{L}$ & Melastomataceae & 1 & - & - & - & 1 \\
\hline 37 & Melicope lunu-ankenda (Gaertn) TG Hartley & Rutacecea & - & 2 & 2 & - & 4 \\
\hline 38 & Memecylon edule Roxb. & Melastomataceae & - & 1 & - & - & 1 \\
\hline 39 & Memecylon paniculatum Jack & Melastomataceae & 6 & - & - & - & 6 \\
\hline 40 & Memecylon umbellatum Burm.f. & Melastomataceae & 4 & 2 & 6 & - & 12 \\
\hline
\end{tabular}




\begin{tabular}{|c|c|c|c|c|c|c|c|}
\hline \multirow{2}{*}{ No } & \multirow{2}{*}{ Scientific name } & \multirow{2}{*}{ Famili } & \multicolumn{4}{|c|}{ Quantity Per Growth Rate } & \multirow[b]{2}{*}{$\Sigma$} \\
\hline & & & Seedling & Sapling & Poles & Trees & \\
\hline 41 & Microcos tomentosa $\mathrm{Sm}$. & Malvaceae & 4 & 19 & 6 & - & 29 \\
\hline 42 & Mischocarpus pentapetalus (Roxb.) Radlk. & Sapindaceae & - & 1 & - & - & 1 \\
\hline 43 & Nephelium cuspiatum Blume & Sapindaceae & - & - & 1 & 2 & 3 \\
\hline 44 & Nephelium lappaceum L & Sapindaceae & - & - & 1 & 2 & 3 \\
\hline 45 & Nephelium maingayi Hiern & Sapindaceae & 219 & 4 & 3 & 9 & 235 \\
\hline 46 & Oncosperma tigillarium (Jack) Ridl & Arecaceae & 23 & 2 & - & - & 25 \\
\hline 47 & Parkia speciosa Hassk & Fabaceae & 1 & - & 1 & 1 & 3 \\
\hline 48 & Pinanga coronata (blume ex Mart.) Blume & Arecaceae & 9 & 8 & - & - & 17 \\
\hline 49 & Piper nigrum $\mathrm{L}$ & Piperaceae & 16 & - & - & - & 16 \\
\hline 50 & Pittosporum ferrugineum W.T. Aiton & Pittosporaceae & 2 & 7 & 2 & 1 & 12 \\
\hline 51 & Psychotria viridiflora Reinw.ex Blume & Rubiaceae & 4 & - & - & - & 4 \\
\hline 52 & Quercus sp & Fagaceae & 1 & - & - & 1 & 2 \\
\hline 53 & Rhodamnia cinerea Jack & Myrtaceae & 23 & 51 & 21 & 8 & 103 \\
\hline 54 & Salacia korthatsiana Miq & Celastraceae & - & 1 & - & - & 1 \\
\hline 55 & Salacia verrucosa Wight & Arecaceae & 2 & - & - & - & 2 \\
\hline 56 & Sandoricum koetjape (Burm.f.) Merr. & Meliaceae & - & - & 2 & 1 & 3 \\
\hline 57 & Sonneratia alba JE Smith & Lythraceae & - & - & - & 1 & 1 \\
\hline 58 & Sterculia oblonga Mast. & Malvaceae & 5 & 2 & - & - & 5 \\
\hline 59 & Symplocos recemosa Roxb. & Symplocaceae & 2 & - & - & - & 2 \\
\hline 60 & Syzygium acuminatissimum (blume) DC & Myrtaceae & 11 & 7 & - & - & 18 \\
\hline 61 & $\begin{array}{l}\text { Syzygium antisepticum (Blume) } \\
\text { Merr.andL.M Perry }\end{array}$ & Myrtaceae & 4 & 1 & - & 6 & 11 \\
\hline 62 & $\begin{array}{l}\text { Syzygium chloranthum (Duthie) Merr and } \\
\text { LM Perry }\end{array}$ & Myrtaceae & 25 & 17 & - & - & 42 \\
\hline 63 & Syzygium grande (Wight)Walp. & Myrtaceae & 12 & 11 & 3 & 67 & 93 \\
\hline 64 & $\begin{array}{l}\text { Syzygium incarnatum (Elmer) Merr and } \\
\text { L.M. Perry }\end{array}$ & Myrtaceae & 4 & 10 & 1 & 7 & 22 \\
\hline 65 & Syzygium jambos (L)Alston & Myrtaceae & - & 1 & 1 & 1 & 3 \\
\hline 66 & $\begin{array}{l}\text { Syzygium luehmannii (F Muell) LAS } \\
\text { Johnson }\end{array}$ & Myrtaceae & - & 2 & 1 & - & 3 \\
\hline 67 & Syzygium nervosum A.Cunn.ex DC & Myrtaceae & - & 1 & - & - & 1 \\
\hline 68 & Syzygium pycnanthum Merr. and LM Perry & Myrtaceae & 158 & 9 & 2 & - & 169 \\
\hline 69 & Syzygium rubiginosum Merr. and L.M. Perry & Myrtaceae & 189 & 60 & 31 & 14 & 294 \\
\hline 70 & Terminalia catappa $\mathrm{L}$ & Combretaceae & - & 1 & 1 & 9 & 11 \\
\hline 71 & Tetracera poggei Gilg & Dilleniaceae & 1 & - & - & - & 1 \\
\hline 72 & Tristaniopis mergueensis Griff. & Myrtaceae & 17 & 4 & 36 & 7 & 64 \\
\hline \multirow[t]{2}{*}{73} & $\begin{array}{l}\text { Tristaniopsis laurina (Sm.) Peter G Wilson } \\
\text { and JT Waterh }\end{array}$ & Myrtaceae & - & 1 & - & - & 1 \\
\hline & & Amount & 1071 & 385 & 172 & 226 & 1858 \\
\hline
\end{tabular}

Table 3 describes the significant value index (IVI) of tree growth rates in the four villages that were observed differently. In the village of Kepoh, the highest IVI value was in the type of Terminalia catappa (83.29\%) of the Combretaceae family which showed a higher density value than other species. Terminalia catappa in Kepoh village mostly grows in watery or swampy habitats. Desa Pasirputih, species of Syzygium grande family Myrtaceae, has the highest IVI (174.33\%). In the village of Batu Betumpang, the species Ficus racemosa of the Moraceae family with an IVI of $127.27 \%$ and Cratoxylum glaucum of the Hipericaceae family in the village of Bencah had the highest IVI of $176.17 \%$. Ecologically it can be explained that the IVI shown 
by each species indicates the presence of that species is considered dominant in the area because it has a higher density, frequency and dominance than other species.

Table 3 Types and analysis of forest food source vegetation observed on tree growth rates in four village KPHP Unit VIII Muntai Palas, South Bangka Regency

\begin{tabular}{llccccc}
\hline \multirow{2}{*}{ Lokasi Pengamatan } & \multicolumn{1}{c}{ Nama Ilmiah } & Famili & $\begin{array}{c}\text { KR } \\
(\%)\end{array}$ & $\begin{array}{c}\text { FR } \\
(\%)\end{array}$ & $\begin{array}{c}\text { DR } \\
(\%)\end{array}$ & IVI (\%) \\
\hline \multirow{5}{*}{ Desa Kepoh } & Sonneratia alba & Lythraceae & 3.57 & 4.76 & 10.47 & 18.81 \\
& Elaeis guineensis & Arecaceae & 7.14 & 9.52 & 18.63 & 35.30 \\
& Terminalia catappa & Combretaceae & 32.14 & 28.57 & 22.58 & 83.29 \\
& Mangifera odorata & Anacardiaceae & 7.14 & 9.52 & 17.74 & 34.40 \\
& Mangifera caesia & Anacardiaceae & 3.57 & 4.76 & 15.09 & 23.43 \\
\hline \multirow{5}{*}{ Desa Pasir Putih } & Myzygium grande & Myrtaceae & 62.62 & 42 & 69.71 & 174.33 \\
& Syzygium rubiginosum & Myrtaceae & 4.67 & 8 & 2.87 & 15.54 \\
& Garcinia xanthochymus & Cluciaceae & 6.54 & 10 & 4.93 & 21.47 \\
& Syzygium incarnatum & Myrtaceae & 6.54 & 12 & 5.24 & 23.79 \\
& Rhodamnia cinerea & Myrtaceae & 7.48 & 12 & 3.87 & 23.35 \\
\hline \multirow{5}{*}{ Besa Batumpang } & Ficus racemosa & Moraceae & 23.08 & 25.00 & 79.19 & 127.27 \\
& Bridelia tomentosa & Phyllanthaceae & 38.46 & 25.00 & 11.43 & 74.90 \\
& Parkia speciosa & Fabaceae & 7.69 & 25.00 & 6.45 & 39.15 \\
& Nephelium lappaceum & Sapindaceae & 15.38 & 16,67 & 2.02 & 34.07 \\
& Caryota mitis & Arecaceae & 15.38 & 8,33 & 0.90 & 24.62 \\
\hline \multirow{5}{*}{ Desa Bencah } & Cratoxylum glaucum & Hipericaceae & 64.10 & 45.16 & 66.85 & 176.12 \\
& Tristaniopsis merguensis & Myrtaceae & 8.97 & 12.90 & 5.87 & 27.75 \\
& Nephelium maingayi & Sapindaceae & 11.54 & 9.68 & 12.84 & 34.05 \\
& Syzygium rubiginosum & Myrtaceae & 7.69 & 16.13 & 7.23 & 31.05 \\
& Syzygium antisepticum & Myrtaceae & 5.13 & 9.68 & 4.56 & 19.37 \\
\hline
\end{tabular}

In Figure 5 each observation location has a different Shannon-Wienner diversity index value. Kepoh village had the highest score at the pole growth rate (2.30), Pasir Putih village at the sapling level (2.21), in Batu Betumpang village at the seedling level (2.26) and Bencah village at the seedling level at 1.86. The diversity index is a quantitative measure (number) that reflects how many different species (such as species) exist in a data set (community). The value of the diversity index in Kepoh village at the high pole growth rate compared to the other three villages. This condition is caused by the diversity of forests ranging from coastal communities, swamp habitats, hilly plains that affect species diversity. The species diversity index is an index that expresses community structure and ecosystem stability. The better the species diversity index, the more stable an ecosystem.

While the condition of the forest as a sample point of observation in Pasir Putih village, Batu Betumpang village has the status of a protected forest (HL) although it starts from the shoreline but does not have species from the coastal community. Meanwhile, specifically for Bencah village, which has the status of forest for other use areas (APL) does not have the sea as a comparison sample.

In Figure 6, the species richness value in KPHP Unit VIII Muntai Palas, South Bangka Regency using the Margalef formula, shows that Kepoh village has a wealth index value of 6.23 or found 30 species from 105 individuals. Followed by Batu Betumpang village with a species richness index value of 4.43 or found 25 species from a total of 226 individuals. 
Figure 7 The evenness index of species in Kepoh village has the highest evenness value (0.86) because Kepoh Village has species with each relatively equal or even number of individuals. Meanwhile, Bencah village has the lowest evenness value (0.68) due to species that have a high number of individuals or dominant species, and the number of individuals in each species is not the same or uneven individual.

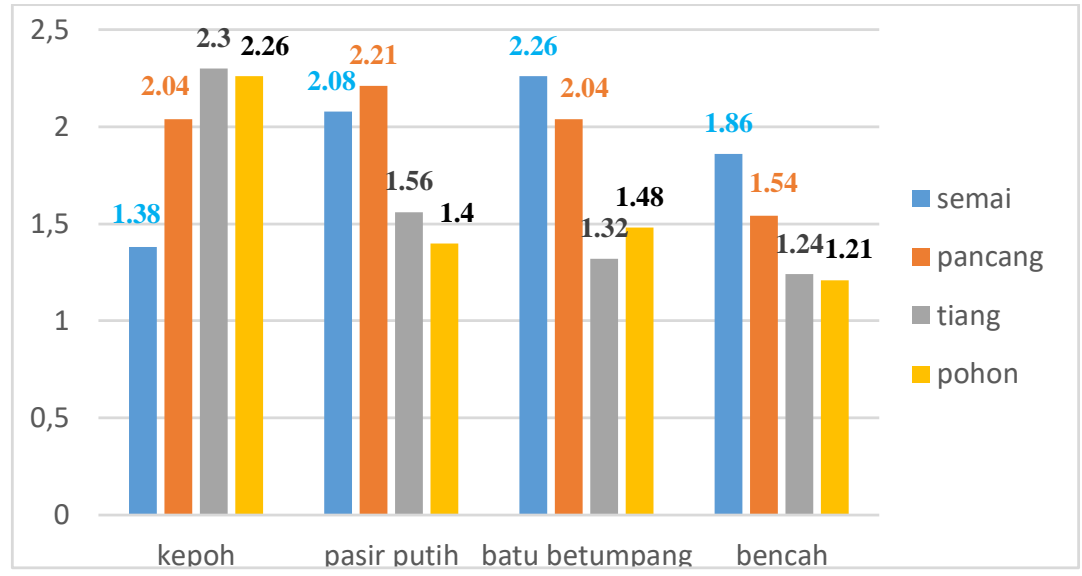

Figure 5 Species diversity index (Shannon-Wienner)

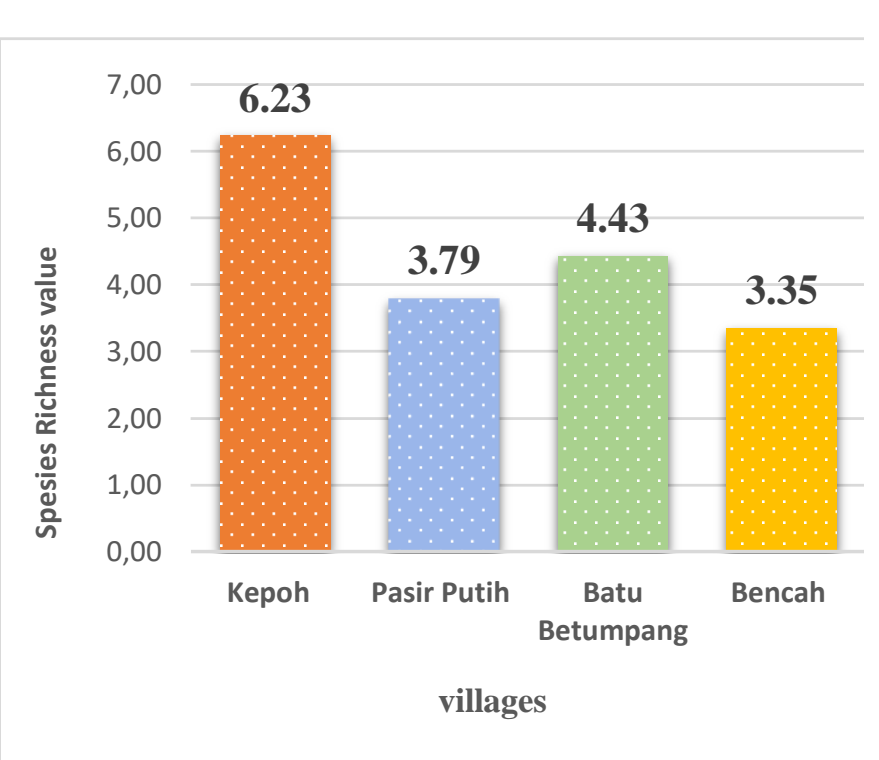

Figure 6 Species richness value

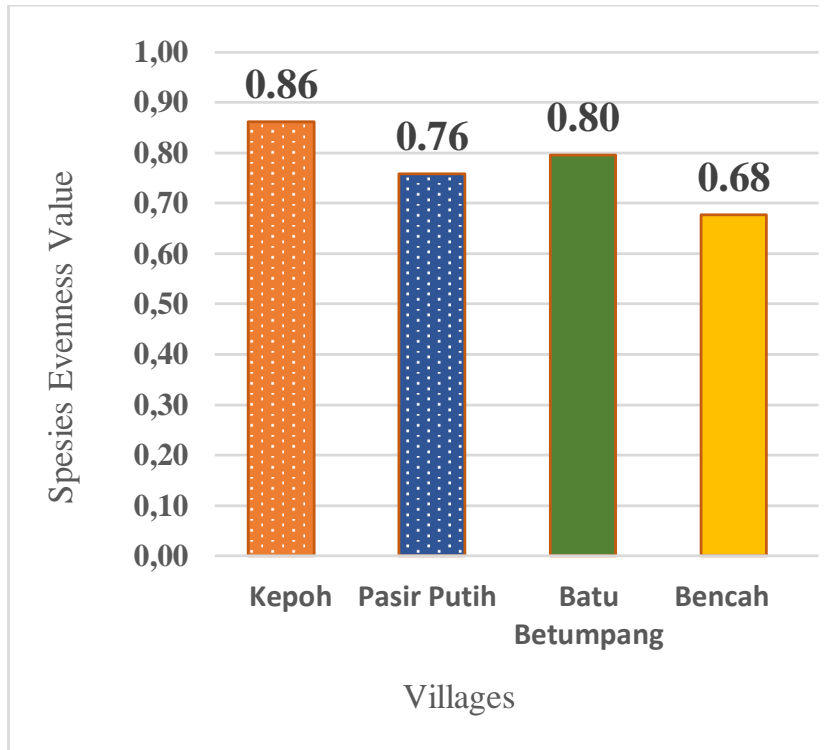

Figure 7 Species evenness value

The evenness index of species in Kepoh village has the highest evenness value (0.86) because Kepoh village has species with each relatively equal or even number of individuals. Meanwhile, Bencah village has the lowest evenness value (0.68) due to species that have a high number of individuals or dominant species, and the number of individuals in each species is not the same or uneven individual.

\section{Analysis of Forest Food Source Plant Utilization}

\section{Local User's Value Index (LUVI) Value}

LUVI is the level of importance shared by a species as a whole even though the interests are different. In Kepoh village the highest fresh food category was 25.31 compared to other categories. the highest importance of the species as a function as a medicinal ingredient (21.06\%). Meanwhile, in Pasir Putih, the largest LUVI 
value is $23.68 \%$, various forest plants can be consumed as fresh food. In Batu Betumpang village, the largest LUVI value (20.79\%) is consumed as fresh food and in Bencah village, the LUVI value of $18.29 \%$ is generally used as medicine.

Based on the results of research by Liza et al. (2020) in the village of Jawai Laut, Sambas Regency that the group of food sources from fruits is the most dominant, there are 34 species (59\%) compared to the groups of vegetables, tubers, spices, sugar cane, and cereals. Zikri's research (2016) explains that the Rejang tribe in Rindu Hati Village, Bengkulu Province utilizes 199 species of food plants. Consists of 58 species of wild food plants and 141 species of cultivated food plants.

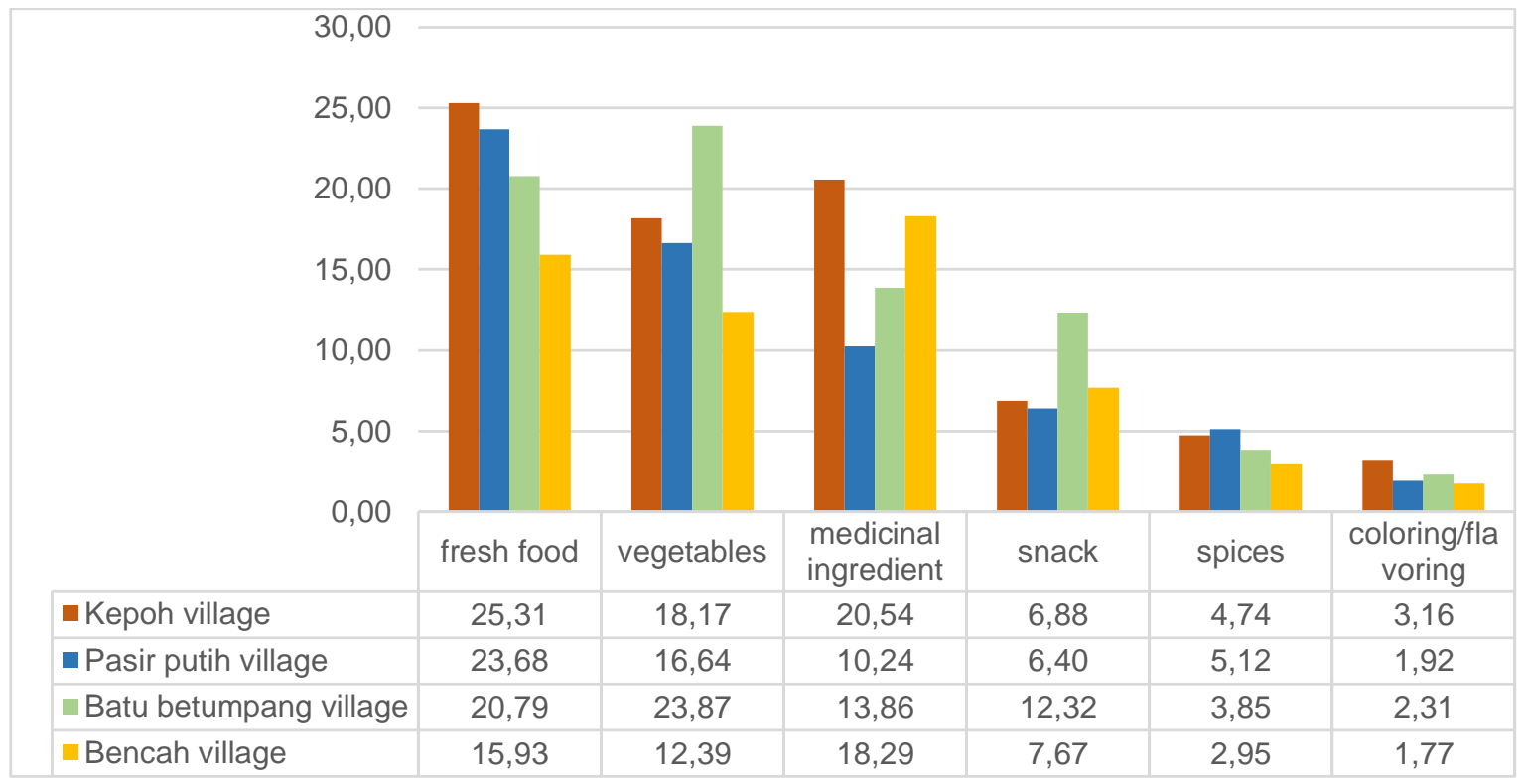

Figure 8 LUVI value for the use of forest food sources

The higher the LUVI value, the more important it is to conserve this species. Based on the results of the LUVI analysis of the species in each village (Figure 8). it was noted that in the village of Kepoh Sandoricum koetjape it had a LUVI value of 11.14, in the village of Pasir Putih Mangifera odorata (LUVI=9.68), Batu Betumpang village was owned by Nephelium lappaceum (LUVI=11.20) and LUVI= 10.84 for Garcinia nigrolineata candida in Bencah village.

\section{Forest Conservation Village Development Strategy}

\section{AHP and SWOT Analysis}

After evaluating internal factors and external factors, the results are shown in Tables 4 and 5. The community-based forest conservation village development strategy based on the SWOT analysis shows a position in quadrant $1(x=0.46$ and $y=0.10)$ (Figure 9) and is progressive by optimizing strengths and taking advantage of opportunities. The strategy of developing forest conservation villages by relying on the value of plant diversity as forest food sources is in a strategic geographical position supported by the topography of the sea, coastal areas, swamps, rivers, lowlands, highlands and with commitment and implementation of regional policies to support sustainable development, forest tourism potential can be developed. Nature, health forest, educational forest as a natural laboratory, and build investment cooperation in the natural resources and environmental sectors. With the quality and quantity of human resources is the power to create innovation and creativity to obtain added value, plant diversification by utilizing technology. Central government support and the potential of forest Natural Resources (SDA) as a source of Regional Original Revenue (PAD) can be an opportunity to get a larger budget allocation. 
Table 4 IFE (Internal Factor Evaluation) matrix

\begin{tabular}{|c|c|c|c|c|c|c|c|c|c|}
\hline No & Internal Factors & Weight & Rating & Score & No & Internal Factors & Weight & Rating & Score \\
\hline \multicolumn{5}{|c|}{ Strength } & \multicolumn{5}{|c|}{ Weakness } \\
\hline S1 & Biodiversity & 0.04 & 4.0 & 0.15 & W1 & $\begin{array}{l}\text { Public } \\
\text { knowledge }\end{array}$ & 0.04 & 2.8 & 0.12 \\
\hline $\mathrm{S} 2$ & $\begin{array}{l}\text { Geographic } \\
\text { position }\end{array}$ & 0.02 & 3.0 & 0.07 & W2 & $\begin{array}{l}\text { Capacity and } \\
\text { performance }\end{array}$ & 0.02 & 3.6 & 009 \\
\hline S3 & $\begin{array}{l}\text { Topographical } \\
\text { conditions }\end{array}$ & 0.03 & 2.4 & 0.08 & W3 & $\begin{array}{l}\text { Coaching } \\
\text { program }\end{array}$ & 0.05 & 3.4 & 0.17 \\
\hline S4 & $\begin{array}{l}\text { Government } \\
\text { commitment }\end{array}$ & 0.14 & 3.0 & 0.43 & W4 & Empowerment & 0.07 & 3.8 & 0.28 \\
\hline S5 & Human resources & 0.14 & 3.2 & 0.44 & W5 & $\begin{array}{l}\text { Society } \\
\text { participation }\end{array}$ & 0.12 & 2.8 & 0.33 \\
\hline S6 & Economic income & 0.08 & 2.6 & 0.21 & W6 & $\begin{array}{l}\text { Potential } \\
\text { promotion }\end{array}$ & 0.11 & 2.4 & 0.25 \\
\hline \multirow[t]{3}{*}{ S7 } & Forest presence & 0.13 & 2.6 & 0.34 & \multicolumn{2}{|c|}{ Total Weakness (W) } & 0.42 & & 1.25 \\
\hline & Total strength (S) & 0.58 & & 1.71 & & & 1 & & 2.96 \\
\hline & & & & & \multicolumn{2}{|c|}{ Total IFAS (S-W) } & & & 0.46 \\
\hline
\end{tabular}

Table 5 EFE (External Factor Evaluation) matrix

\begin{tabular}{|c|c|c|c|c|c|c|c|c|c|}
\hline No & External Factors & Weight & Rating & Score & No & External Factors & Weight & Rating & Score \\
\hline \multicolumn{5}{|c|}{ Opportunity } & \multicolumn{5}{|c|}{ Threat } \\
\hline $\mathrm{O} 1$ & Functional forest & 0.06 & 3.8 & 0.21 & $\mathrm{~T} 1$ & Illegal mining & 0.11 & 2.4 & 0.27 \\
\hline $\mathrm{O} 2$ & $\begin{array}{l}\text { Innovation and } \\
\text { creativity }\end{array}$ & 0.03 & 3.0 & 0.09 & $\mathrm{~T} 2$ & $\begin{array}{l}\text { Forest } \\
\text { destruction }\end{array}$ & 0.16 & 2.8 & 0.44 \\
\hline $\mathrm{O} 3$ & $\begin{array}{l}\text { Natural resource } \\
\text { invenstment }\end{array}$ & 0.13 & 3.6 & 0.47 & $\mathrm{~T} 3$ & $\begin{array}{l}\text { Crisis of } \\
\text { confidence }\end{array}$ & 0.14 & 2.8 & 0.38 \\
\hline $\mathrm{O} 4$ & Plant diversification & 0.09 & 3.4 & 0.31 & $\mathrm{~T} 4$ & $\begin{array}{l}\text { People's } \\
\text { plantation }\end{array}$ & 0.14 & 2.2 & 0.31 \\
\hline O5 & $\begin{array}{l}\text { Allocation of } \\
\text { village funds }\end{array}$ & 0.06 & 3.4 & 0.22 & & Total Threat (T) & 0.55 & & 1.40 \\
\hline O6 & $\begin{array}{l}\text { Technological } \\
\text { progress }\end{array}$ & 0.09 & 2.4 & 0.21 & & Total & 1.00 & & 2.90 \\
\hline & tal Opportunity (O) & 0.45 & & 1.50 & & otal EFAS (O-T) & & & 0.10 \\
\hline
\end{tabular}




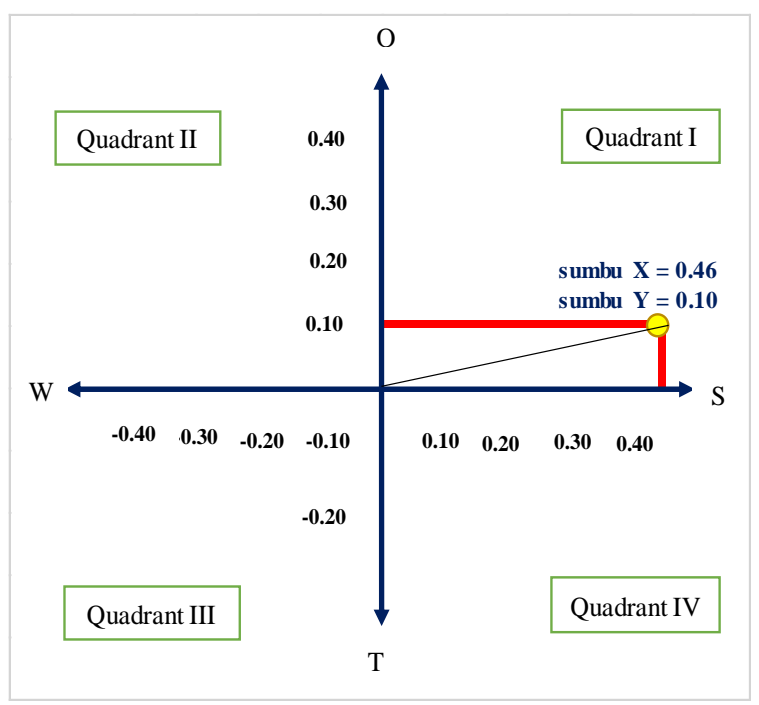

Figure 9 Position of the SWOT quadrant for conservation village development

\section{CONCLUSION}

The wealth of forest biodiversity in the form of forest food plants found in the research area both in quality and quantity is the capital for the development of the forestry sector. This potential becomes a consideration for forest conservation and forest land use decision makers, especially in the development of forest conservation villages. Forest food products can support village food security programs in facing the threat of a food crisis. The number of species inventoried is 73 species, 54 genera and 33 families.

The importance of the use of forest food source plants calculated by the LUVI (Local User's Value Index) analysis shows the potential for valuable food, namely the choice of food sources that are most needed by the community, most exploited and have a threat of extinction for these resources so that they can disrupt village food security. Therefore, it is necessary to conserve and develop species based on LUVI values. The higher the LUVI value, the more important it is to conserve this species. In the village of Kepoh Sandoricum koetjape it has the highest LUVI value of 11.14, the village of Pasir Putih Mangifera odorata has a LUVI of 9.68, in the village of Batu Betumpang it is owned by Nephelium lappaceum with a LUVI of 11.20 and in the village of Bencah Garcinia nigrolineata it has a LUVI value of 10.84 .

Forest conservation village development strategies supported by food plant resources, human resources and government policies can be developed as natural tourism forests, health forests, educational forests as natural laboratories, building investment cooperation in the natural resource sector, creating innovation and creativity to obtain added value, diversifying plants by utilizing technology and increasing sources of income.

\section{REFERENCES}

[BPS] Badan Pusat Statistik. 2021. Kabupaten Bangka Selatan Dalam Angka. Bangka Selatan (ID): Badan Pusat Statistik Kabupaten.

[CIFOR] Center for International Forestry Research. 2000. Building an agenda together (bangun rencana bersama II). ACM Report of Workshop; 2000 Dec 4-6 Desember 2000; Malinau, Indonesia. Bogor (ID): CIFOR.

[Kemhut] Kementerian Kehutanan. 2009. Keputusan Menteri Kehutanan Nomor: SK.797/MENHUT-II/2009 tentang Penetapan Wilayah Kesatuan Pengelolaan Hutan Lindung (KPHL) dan Kesatuan Pengelolaan Hutan Produksi (KPHP) Provinsi Kepulauan Bangka Belitung. Jakarta (ID): Kemhut. 
[KLHK] Kementerian Lingkungan Hidup dan Kehutanan. 2018. Rencana Pengelolaan Hutan Jangka Panjang Kesatuan Pengelolaan Hutan Produksi (KPHP) Unit VIII Muntai Palas Kabupaten Bangka Selatan Provinsi Kepulauan Bangka Belitung Tahun 2019-2028. Jakarta (ID): KLHK.

Frey JH, Fontana A. 2009. Wawancara seni ilmu pengetahuan. In: Denzin NK, Lincoln YS. Handbook Of Qualitative Research. Yogyakarta (ID): Pustaka Pelajar.

Gadgil MP, Achar K, Shetty A, Ganguly A, Nagendra H, Bhat HR, Venkatesan J, Krishna K, Kunte K, Moolya K, et al. 2000. Participatory Local Level Assessment of Life Support System, A Methodology Manual. Technical Report No. 78 Centre Ecological Science. India (IN): Indian Institute of Science Bangalore.

Kusmana C. 2017. Metode Survey dan Interpetasi Data Vegetasi. Bogor (ID): IPB Press.

Liza, Oramahi HA, Sisillia L. 2020. Jenis Tumbuhan yang Dimanfaatkan sebagai sumber pangan oleh masyarakat Desa Jawai Laut Kecamatan Jawai Selatan Kabupaten Sambas. Jurnal Hutan Lestari (2020). 8(2): 315-324.

Magurran AE. 1988. Ecological Diversity and It's Measurement. New Jersey (US): Princeton University Pr. Princeton.

Odum EP. 1993. Dasar-Dasar Ekologi. Yogyakarta (ID): Gadjah Mada University Press Jogjakarta. Translate from: Fundamentals of ecology.

Rangkuti. 1997. Analisis SWOT Teknik Membedah Kasus Bisnis-Reorientasi Konsep Perencanaan Strategis untuk Menghadapi Abad 21. Jakarta (ID): Gramedia Pustaka Utama.

Saaty TL. 1991. Decision Making for Leader: The Analitical Hierarchy Process For Decision In Complex World, Prentice Hall Coy. Pennsylvania (US): RWS Publication.

Sheil D, Puri RK, Basuki I, Heist MV, Wan M, Liswanti N, Rukmiyati, Sardjono MA, Samsoedin I, Sidiyasa K, Chrisandini, et al. 2004. Mengeksplorasi Keanekaragaman Hayati, Lingkungan dan Pandangan Masyarakat Lokal Mengenai Berbagai Lanskap Hutan, Metode-metode Penilaian Lanskap Secara Multidisipliner. Bogor (ID): CIFOR Bogor Indonesia.

Soerianegara I, Indrawan A. 1998. Ekologi Hutan Indonesia. Bogor (ID): Fakultas Kehutanan IPB.

Solusu J. 2000. Pengambilan Keputusan Stratejik. Jakarta (ID): Gramedia.

Togola A, Drissa D, Seydou D, Hilde B, Berit SP. 2005. Ethnopharmacological survey of different uses of seven medicinal plant from Mali, (West Africa) In The Regions Doila, Kolokani and Siby. Journal of Ethnobiology and Ethnomedicine. 1(7): 1-9. doi: https://doi.org/10.1186/1746-4269-1-7.

Zikri M. 2016. Retensi pengetahuan tumbuhan pangan suku rejang di Kampung Rindu Hati dalam ketahanan pangan. Media Konservasi. 21(3): 270-277.

Zuhud EAM. 2011. Pengembangan Desa Konservasi Hutan Keanekargaman Hayati untuk Mendukung Kedaulatan Pangan dan Obat Keluarga (POGA) Indonesia dalam Menghadapi Ancaman Krisis Baru Ekonomi Dunia di Era Globalisasi. Bogor (ID): Orasi Ilmiah Guru Besar IPB. 